\title{
Strategic Planning for Sustainability in a Start-Up Company: A Case Study on Human Resources Consulting Firm
}

\author{
By Burcu Gurel ${ }^{1}$, Irem Ucal Sari ${ }^{2}$
}

\begin{abstract}
With the increasing globalization, companies try to be more specialized on the market to become prominent among their competitors. This fact leads managers to recruit qualified and experienced personnel, which is an expensive and effortful process. Recruitment process has critical importance to find out the most adequate personnel. The most significant difficulty in that process is to find the right person in a short time period with a relatively small budget which requires a rich portfolio. Due to the difficulties in creating a rich portfolio and eliminating the candidates, companies prefer outsourcing human resources processes. Therefore human resources consulting firms have become more widespread to meet the needs of the companies on the experienced and qualified human resources. The purpose of this paper is to find out the primal growth strategies for a start-up human consulting firm to make sure the sustainability of the company. The paper utilizes extended SWOT analysis to determine primary strategies and balanced score card (BSC) approach to determine the best growth strategy with a real case study.
\end{abstract}

Keywords: Strategic management, Sustainable strategic planning, Start-ups, Balanced Scorecard, SWOT analysis

\section{Introduction}

A start-up company is an organization which is in the early stages of its operations. Mostly the start-up companies searches for a new and repeatable business model. Of course the risks of a start-up company are higher than the companies which have a stable profit and market share. Therefore it is important to analyze the potentials and threats in the sector.

Strategic management is important for all companies but it is essential for the start-up companies. One of the key components of start-up companies is the ability to grow. For a start-up company there are lots of strategies which could be used to grow and to be successful. To determine the most critical strategy is the thing which directly affects the survival of a start-up company. The strategies of a start-up company are different than others. A start-up company's strategies focus on increasing market share where the other companies have strategies which focus on increasing profits. So, strategic management analysis is crucial for start-up companies.

Nowadays, specialization has become more important for companies to have competitive advantage on the industry. Specialization increases the need for the qualified employees which makes recruitment process more critical for the company. Therefore the human resources department of a specialized company has to be managed well. The personnel of this department should have the ability of evaluating the candidates to find out the most adequate personnel for a special job which makes the total cost of human resources departments higher. The high cost of the human resources departments directs companies outsourcing human recruitment processes. As a result of this, the number of human resources consulting firms is increasing day by day and 
the human resources consulting industries are growing fast. It is seen that new business models on human resources consulting industry have been introduced.

In this paper it is aimed to develop a method to determine the most critical strategy which will make a start-up human resources consulting company live longer and be successful. In the proposed method extended SWOT analysis and Balance Score Card (BSC) approach are used to determine the strategies and select the most suitable one.

The paper is constructed as follows: First a literature review on SWOT analysis and BSC methods are given. Then in the methodology section steps of the proposed method are given. In the application section a real case of a start-up human resources consulting firm is examined. Finally the paper is concluded with the discussion of the results.

\section{Literature review}

Strategic management of start-up companies is an interesting subject due to the increasing attention on start-ups. Boyett and Currie (2004) highlighted the elements of strategy design, organizational structure and human resource management for an Irish start-up company. Hsu (2006) analyzed the possible impact of venture capital assistance on the commercialization direction of technology-based start-ups. Davila et al. (2014) examined management control systems adopted by start-up companies. In the literature review, it is seen that the papers deal with strategic management does not focus on determination of the strategic road maps for the start-up companies. Therefore there is a need for a methodology to define the best strategy for start-ups.

SWOT (Strengths, Weaknesses, Opportunities, Threats) analysis is one of the most used strategic management tools. Jackson et al. (2003) analyzed previous studies to assess the effects of workplace diversity on teams and organizations using SWOT analysis. Yuksel and Dagdeviren (2007) proposed an algorithm which combines analytic network process and SWOT analysis to measure and consider the possible dependency among the factors. Dyson (2004) used SWOT analysis for strategy formulation and its incorporation into the strategic development process at a university. Houben et al. (1999) proposed a knowledge-based SWOT analysis system for strategic planning in small and medium sized companies. Kazana et al. (2015) used SWOT for sustainable forest management assessment in Greece. Patnaik and Poyyamoli (2015) used SWOT analysis to identify the potential and constraints for the successful implementation of an eco-industrial park in an ecologically fragile coastal zone.

There are also some articles which combine SWOT and BSC approaches. Tsalis et al. (2013) provided a framework, based on SWOT analysis, to facilitate the investigation of managers' opinions of small and medium enterprises regarding BSC implementation. Zohrabi and Manteghi (2011) developed a methodology which utilizes SWOT analysis to formulate initial strategies of the organization, BSC to allocate the strategies and house of quality approach to select the strategies. Fouladgar et al. (2011) proposed an integrated model combining SWOT, BSC and fuzzy analytical hierarchy process approaches for prioritizing the strategies of Iranian mining sector.

In the proposed methodology SWOT analysis and BSC approaches are combined to plot the strategic map of the start-up companies.

\section{Methodology}

The proposed strategic management method has 8 steps.

Step 1. Perform SWOT analysis of the company. In this step the organization is examined in terms of its strengths and weaknesses, and the external environment is examined in terms of 
opportunities and threats.

Step 2. Perform Extended-SWOT matrix. In this step the managers develop four types of strategies. Aggressive strategy (SO) uses organization's internal strengths to take advantage of external opportunities. Cautious strategy (WO) aims at improving internal weaknesses by taking advantage of external opportunities. Competition strategy (ST) uses an organization's strengths to avoid or reduce the impact of external threats. Defensive strategy (WT) aims reducing internal weakness and avoiding external threats (David, 2009). In Figure 1, four dimensions of extended SWOT matrix is given.

\begin{tabular}{c|cc} 
SWOT & Strengths List (S) & Weakness List (W) \\
\hline Opportunities List (O) & SO Strategies (Max-Max) & WO Strategies (Min-Max) \\
Threats List (T) & ST Strategies (Max-Min) & WT Strategies (Min-Min)
\end{tabular}

Figure 1. Extended SWOT Matrix

Step 3. Perform Internal Factors Evaluation (IFE) Matrix. The factors determined strengths and weaknesses are weighted in a way that the sum of these weights is equal to one. Then, a rating in the range between 1 and 4 is allocated to each factor where 1 denotes severe weakness, 2 shows common weakness, 3 indicates for a common strength and finally 4 brings out important strengths. Weighted scores of the factors are assessed by multiplying weight by rating (Nouri et al., 2008).

Step 4. Perform External Factors Evaluation (EFE) Matrix. EFE matrix is constructed similar to IFE matrix taking external factors instead of internal factors.

Step 5. Perform Internal-External Matrix (IE). The IE Matrix plots organization divisions in a schematic diagram. The IE Matrix is based on two key dimensions: the IFE total weighted scores on the $\mathrm{x}$-axis and the EFE total weighted scores on the $\mathrm{y}$-axis. The total weighted scores derived from the divisions allow construction of the corporate-level IE Matrix (David, 2009). On the xaxis of the IE Matrix, an IFE total weighted score of 1.0 to 2.5 represents a weak internal position; a score of 2.5 to 4 is considered strong. Similarly, on the y-axis, an EFE total weighted score of 1.0 to 2.5 is considered threat; and a score of 2.5 to 4.0 is opportunity.

Step 6. Perform Quantity Strategic Planning Matrix (QSPM). The QSPM is designed to prioritize or determine the attractiveness of the strategies generated in the EFE and IFE matrices (Wang et al., 2008). In the QSPM cells each strategy is rated by an attractiveness score (AS). Total attractiveness score (TAS) is calculated by multiplying weight and AS. The sums of TAS of each strategy are compared with the aim of finding the best strategy. The strategy which has the highest total TAS, is the most attractive strategy (David, 2009).

Step 7: Classify SWOT factors in BSC dimensions. The internal and external factors are classified into four perspectives which are customer, business internal processes, growth-innovation of organization and financial factors (Kaplan and Norton, 1992).

Step 8: Plot Strategic Map. Strategic map is a general representation of the factors linked to the four BSC perspectives (Kaplan and Norton, 2004). The sub-strategies are generated by decision makers according to these links to support the main strategy. At the end of this step decision makers select and apply the most suitable sub-strategies.

\section{Application: A Case Study on Human Resources Consulting Company}

The proposed method is applied to a start-up human resources consulting company which is located in Istanbul and established in 2013. Since then, company had taken the 
development progress. The company searches for a new business model in human resources consulting industry. They use a web- based database system and interviews are done both face to face and via internet. The interviews are recorded and the records of final candidates for an open job position are shared with the clients.

SWOT analysis is done for the company on a workshop that attended by co-founders. The results of this analysis are given in Table 1.

Table 1: SWOT Matrix of the Start-up Company

\begin{tabular}{|c|c|c|c|}
\hline & Strengths (S) & & Weakness (W) \\
\hline 1 & Founders' recognition in and about sector & 1 & Uncertainty in organizational structure \\
\hline 2 & Fastness in making and implementing decisions & 2 & Low income \\
\hline 3 & Developed intimacy with target market & 3 & $\begin{array}{l}\text { Need for growth to reach a sustainable revenue } \\
\text { model }\end{array}$ \\
\hline 4 & Developing software in-house & 4 & $\begin{array}{l}\text { Commitment to high quality operations thus } \\
\text { pressure of need of success }\end{array}$ \\
\hline 5 & Specification and focus of company definition & 5 & $\begin{array}{l}\text { No foreign language support both in products } \\
\text { and services }\end{array}$ \\
\hline 6 & \begin{tabular}{|l}
$\begin{array}{l}\text { Expertise in advertising, marketing and content } \\
\text { management }\end{array}$ \\
\end{tabular} & 6 & No $100 \%$ dedicated personnel \\
\hline 7 & \begin{tabular}{|l|l|} 
Healthy intercommunication \\
\end{tabular} & 7 & Different priorities in top management \\
\hline 8 & Wide network for collaboration with powerful brands & 8 & No regular office utilization \\
\hline 9 & Experienced legal adviser & & \\
\hline 10 & $\begin{array}{l}\text { Having a legal license for recruitment processes from } \\
\text { Turkish Employment Agency }\end{array}$ & & \\
\hline & Opportunities (O) & & Threats (T) \\
\hline 1 & Low competition in sectors' current situation & 1 & $\begin{array}{l}\text { Current and potential economic situation of the } \\
\text { country }\end{array}$ \\
\hline 2 & \begin{tabular}{|l}
$\begin{array}{l}\text { Positive growth and improvement of web-based } \\
\text { services }\end{array}$ \\
\end{tabular} & 2 & $\begin{array}{l}\text { Resistance of product and services' buyer to the } \\
\text { business model }\end{array}$ \\
\hline 3 & High degree of user loyalty & 3 & Possible new-entries to the market \\
\hline 4 & Abundance of office space and low rents & 4 & $\begin{array}{l}\text { Possible change in focus of a major human- } \\
\text { resources company }\end{array}$ \\
\hline 5 & Investor-rich environment & & \\
\hline
\end{tabular}

By using the results of SWOT matrix the strategies for the start-up company are defined by managers. The strategies are grouped in the Extended SWOT Matrix and given in Table 2.

Table 2: Extended SWOT Matrix of the Start-up Company

\begin{tabular}{|c|c|c|}
\hline & Strengths (S) & Weakness (W) \\
\hline \multirow{5}{*}{$\begin{array}{l}: \\
: \\
: \\
0 \\
0 \\
0 \\
0 \\
0 \\
0\end{array}$} & Aggressive Strategy (SO) & Cautious strategy (WO) \\
\hline & $\begin{array}{l}\text { SO1 - The strategy of quickly penetrating brands and } \\
\text { agencies }(\mathrm{S} 1, \mathrm{~S} 2, \mathrm{~S} 5, \mathrm{~S} 8, \mathrm{O} 1, \mathrm{O} 4)\end{array}$ & $\begin{array}{l}\text { WO1 - Moving into a new office with better } \\
\text { defined administrative roles and new personnel } \\
\text { (W2,W4,W5,O1,O2,O6) }\end{array}$ \\
\hline & $\begin{array}{l}\mathrm{SO} 2 \text { - The strategy of increasing number of CV's and } \\
\text { portfolios through advertising (S1,S6,S8,O1,O2,O3) }\end{array}$ & $\begin{array}{l}\text { WO2- Making a } 2 \text { year budget and maintaining it } \\
\text { with a financial controller (W2,W3,W6,W7, O6) }\end{array}$ \\
\hline & $\begin{array}{l}\text { SO3 - The strategy of increasing recognition of the } \\
\text { company and its services }(\mathrm{S} 1, \mathrm{~S} 3, \mathrm{~S} 6, \mathrm{O} 1, \mathrm{O} 3)\end{array}$ & \\
\hline & $\begin{array}{l}\text { SO4 - The strategy of making new products and } \\
\text { services (S4,S9,S10,O1,O2) }\end{array}$ & \\
\hline \multirow[b]{2}{*}{$\frac{\overbrace{\tilde{J}}^{\mathscr{J}}}{\mathrm{Z}}$} & Competition strategy (ST) & Defensive strategy (WT) \\
\hline & $\begin{array}{l}\text { ST1 - The strategy of positioning as a cheap } \\
\text { recruitment alternative and promoting the new } \\
\text { positioning }(\mathrm{S} 1, \mathrm{~S} 4, \mathrm{~T} 5)\end{array}$ & $\begin{array}{l}\text { WT1 - The strategy for selling bulk products and } \\
\text { making long term contacts at low profit marging }\end{array}$ \\
\hline
\end{tabular}


After constructing the SWOT matrix, IFE and EFE matrices are prepared by using the weights and the ratings which are determined by decision makers and given in Table 3 and 4, respectively.

Table 3. IFE Matrix of the Start-up Company

\begin{tabular}{|c|l|c|c|c|c|c|}
\hline No & Factor & Code & Weight & Rating & Weighted Score \\
\hline \multicolumn{2}{|l|}{ Strengths (S) } & S1 & 0.07 & 4 & 0.28 \\
\hline 1 & Founders' recognition in and about sector & S2 & 0.05 & 4 & 0.20 \\
\hline 2 & Fastness in making and implementing decisions & S3 & 0.05 & 4 & 0.20 \\
\hline 3 & Developed intimacy with target market & S4 & 0.06 & 3 & 0.18 \\
\hline 4 & Developing software in-house & S5 & 0.03 & 3 & 0.09 \\
\hline 5 & Specification and focus of company definition & S6 & 0.07 & 4 & 0.28 \\
\hline 6 & $\begin{array}{l}\text { Expertise in advertising, marketing and content } \\
\text { management }\end{array}$ & S7 & 0.05 & 3 & 0.15 \\
\hline 7 & Healthy intercommunication & S9 & 0.03 & 3 & 0.24 \\
\hline 8 & Wide network for collaboration with powerful brands & S8 & 0.06 & 4 & 0.09 \\
\hline 9 & Experienced legal adviser & S10 & 0.10 & 4 & 0.40 \\
\hline 10 & $\begin{array}{l}\text { Having a legal license for recruitment processes from } \\
\text { Turkish Employment Agency }\end{array}$ & & & & \\
\hline
\end{tabular}

Table 3. IFE Matrix of the Start-up Company (Cont.)

\begin{tabular}{|c|l|c|c|c|c|}
\hline No & Factor & Code & Weight & Rating & Weighted Score \\
\hline Weakness (W) & W1 & 0.08 & 2 & 0.16 \\
\hline 1 & Uncertainty in organizational structure & W2 & 0.07 & 2 & 0.14 \\
\hline 2 & Low income & W3 & 0.04 & 2 & 0.08 \\
\hline 3 & Need for growth to reach a sustainable revenue model & W4 & 0.06 & 1 & 0.06 \\
\hline 4 & $\begin{array}{l}\text { Commitment to high quality operations thus pressure of } \\
\text { need of success }\end{array}$ & W5 & 0.03 & 1 & 0.03 \\
\hline 5 & No foreign language support both in products and services & W6 & 0.06 & 2 & 0.12 \\
\hline 6 & No 100\% dedicated personnel & W7 & 0.04 & 2 & 0.08 \\
\hline 7 & Different priorities in top management & W8 & 0.05 & 1 & 0.05 \\
\hline 8 & No regular office utilization & Total & $\mathbf{1 . 0 0}$ & & $\mathbf{2 . 8 3}$ \\
\hline & &
\end{tabular}

Table 4. EFE Matrix of the Start-up Company

\begin{tabular}{|c|l|c|c|c|c|c|}
\hline No & Factor & Code & Weight & Rating & Weighted Score \\
\hline Opportunities (O) & O1 & 0.22 & 4 & 0.88 \\
\hline 1 & Low competition in sectors' current situation & O2 & 0.15 & 3 & 0.45 \\
\hline 2 & Positive growth and improvement of web-based services & O3 & 0.09 & 3 & 0.27 \\
\hline 3 & High degree of user loyalty & O4 & 0.08 & 3 & 0.24 \\
\hline 4 & Abundance of office space and low rents & O5 & 0.07 & 1 & 0.07 \\
\hline 5 & Investor-rich environment & T1 & 0.15 & 1 & 0.15 \\
\hline Threats (T) & T2 & 0.08 & 2 & 0.16 \\
\hline 1 & Current and potential economic situation of the country & T3 & 0.10 & 2 & 0.20 \\
\hline 2 & $\begin{array}{l}\text { Resistance of product and services' buyer to the business } \\
\text { model }\end{array}$ & T4 & 0.06 & 2 & 0.12 \\
\hline 3 & Possible new-entries to the market & Total & $\mathbf{1 . 0 0}$ & & $\mathbf{2 . 5 4}$ \\
\hline 4 & Possible change in focus of a major human-resources company \\
\hline & \multicolumn{5}{|l}{} \\
\hline
\end{tabular}

Then, the results of IFE and EFE are used to construct Internal-External Matrix which is given in Figure 2. 


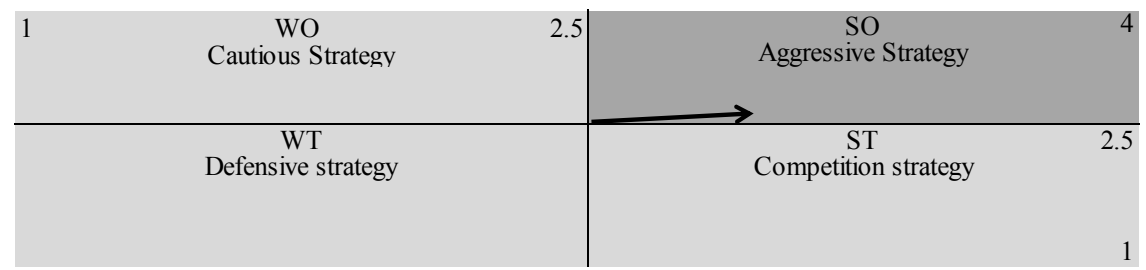

Figure 2. Internal-External Martix

The total weighted scores shows us the best strategy for the company belongs to the aggressive strategy category. But it is also seen that the best strategy is closer to the competition strategy category.

Attractiveness scores (AS) which indicate how each factor is important or attractive to each alternative strategy are determined by decision makers to calculate the total attractiveness scores in the quantity strategic planning matrix. Quantity strategic planning matrix is given in Table 5 .

Table 5: Quantity Strategic Planning Matrix (QSPM)

\begin{tabular}{|c|c|c|c|c|c|c|c|c|c|}
\hline \multirow{2}{*}{ Strenghts } & \multirow{2}{*}{ Weight } & \multicolumn{2}{|c|}{ SO1 } & \multicolumn{2}{|c|}{$\mathrm{SO} 2$} & \multicolumn{2}{|c|}{ SO3 } & \multicolumn{2}{|c|}{ SO4 } \\
\hline & & AS & TAS & AS & TAS & AS & TAS & AS & TAS \\
\hline S1 & 0.07 & 4 & 0.28 & 4 & 0.28 & 4 & 0.28 & 3 & 0.21 \\
\hline S2 & 0.05 & 4 & 0.20 & 2 & 0.10 & 2 & 0.10 & 2 & 0.10 \\
\hline S3 & 0.05 & 2 & 0.10 & 3 & 0.15 & 4 & 0.20 & 3 & 0.15 \\
\hline S4 & 0.06 & 2 & 0.12 & 2 & 0.12 & 1 & 0.06 & 4 & 0.24 \\
\hline S5 & 0.03 & 4 & 0.12 & 3 & 0.09 & 2 & 0.06 & 2 & 0.06 \\
\hline S6 & 0.07 & 3 & 0.21 & 4 & 0.28 & 4 & 0.28 & 2 & 0.14 \\
\hline S7 & 0.05 & 2 & 0.10 & 2 & 0.10 & 2 & 0.10 & 3 & 0.15 \\
\hline S8 & 0.06 & 4 & 0.24 & 4 & 0.24 & 3 & 0.18 & 2 & 0.12 \\
\hline S9 & 0.03 & 1 & 0.03 & 1 & 0.03 & 1 & 0.03 & 4 & 0.12 \\
\hline S10 & 0.10 & 2 & 0.20 & 3 & 0.30 & 3 & 0.30 & 4 & 0.40 \\
\hline Weakness & Weight & AS & TAS & AS & TAS & AS & TAS & AS & TAS \\
\hline W1 & 0.08 & 2 & 0.16 & 1 & 0.08 & 2 & 0.16 & 2 & 0.16 \\
\hline W2 & 0.07 & 4 & 0.28 & 4 & 0.28 & 3 & 0.21 & 2 & 0.14 \\
\hline W3 & 0.04 & 4 & 0.16 & 3 & 0.12 & 4 & 0.16 & 3 & 0.12 \\
\hline W4 & 0.06 & 3 & 0.18 & 2 & 0.12 & 3 & 0.18 & 2 & 0.12 \\
\hline W5 & 0.03 & 2 & 0.06 & 2 & 0.06 & 2 & 0.06 & 2 & 0.06 \\
\hline W6 & 0.06 & 4 & 0.24 & 2 & 0.12 & 3 & 0.18 & 3 & 0.18 \\
\hline W7 & 0.04 & 2 & 0.08 & 3 & 0.12 & 2 & 0.08 & 4 & 0.16 \\
\hline W8 & 0.05 & 2 & 0.10 & 3 & 0.15 & 3 & 0.15 & 3 & 0.15 \\
\hline Total & & & 2.86 & & 2.74 & & 2.77 & & 2.78 \\
\hline Opportunities & Weight & AS & TAS & AS & TAS & AS & TAS & AS & TAS \\
\hline O1 & 0.22 & 4 & 0.88 & 4 & 0.88 & 4 & 0.88 & 4 & 0.88 \\
\hline $\mathrm{O} 2$ & 0.15 & 2 & 0.30 & 4 & 0.60 & 3 & 0.45 & 4 & 0.60 \\
\hline $\mathrm{O} 3$ & 0.09 & 3 & 0.27 & 4 & 0.36 & 4 & 0.36 & 3 & 0.27 \\
\hline O4 & 0.08 & 4 & 0.32 & 2 & 0.16 & 2 & 0.16 & 2 & 0.16 \\
\hline O5 & 0.07 & 2 & 0.14 & 1 & 0.07 & 2 & 0.14 & 2 & 0.14 \\
\hline Threats & Weight & AS & TAS & AS & TAS & AS & TAS & AS & TAS \\
\hline T1 & 0.15 & 4 & 0.60 & 2 & 0.30 & 2 & 0.30 & 3 & 0.45 \\
\hline T2 & 0.08 & 2 & 0.16 & 2 & 0.16 & 2 & 0.16 & 2 & 0.16 \\
\hline T3 & 0.10 & 3 & 0.30 & 3 & 0.30 & 3 & 0.30 & 3 & 0.30 \\
\hline $\mathrm{T} 4$ & 0.06 & 3 & 0.18 & 3 & 0.18 & 3 & 0.18 & 3 & 0.18 \\
\hline Total & & & 3.15 & & 3.01 & & 2.93 & & 3.14 \\
\hline
\end{tabular}


The results of the QSPM is given in Table 6 which shows SO1 - The strategy of quickly penetrating brands and agencies is the best strategy for the company. SO1 is linked to the strengths named by S1, S2, S5, S8 and opportunities named by O1 and O4. It is also seen that SO4 is the second most important strategy for the company which has a total attractiveness score close to SO1.

Table 6: Total Attractiveness Scores of Strategies

\begin{tabular}{|c|c|c|c|c|}
\hline $\begin{array}{ll}\text { Total Attractiveness Scores } & \text { Strategies } \\
\end{array}$ & SO1 & SO2 & SO3 & SO4 \\
\hline Internal & 2.86 & 2.74 & 2.77 & 2.78 \\
\hline External & 3.15 & 3.01 & 2.93 & 3.14 \\
\hline Average & 3.005 & 2.875 & 2.85 & 2.96 \\
\hline
\end{tabular}

After determination of the most important strategy for the company strengths, weaknesses, opportunities and threats are classified by BSC approach and given in Table 7.

Table 7: Classification of SWOT factors in BSC dimensions

\begin{tabular}{|c|c|c|c|}
\hline Customer & $\begin{array}{c}\text { Business internal } \\
\text { processes }\end{array}$ & $\begin{array}{c}\text { Growth, innovation of } \\
\text { organization }\end{array}$ & $\begin{array}{c}\text { Financial } \\
\text { Factors }\end{array}$ \\
\hline $\begin{array}{c}\text { S1, S3, S5, S8, W4, } \\
\text { W5, O3, T2 }\end{array}$ & $\begin{array}{c}\text { S4, S7, S9, S10, W1, W6, } \\
\text { W7, W8 }\end{array}$ & S2, S6, O1, O2, T3, T4 & $\begin{array}{c}\text { W2, W3, O4, } \\
\text { O5, T1 }\end{array}$ \\
\hline
\end{tabular}

Strategic map is plotted to reach SO1 (The strategy of quickly penetrating brands and agencies) using the classified SWOT factors based on BSC dimensions in Figure 3.

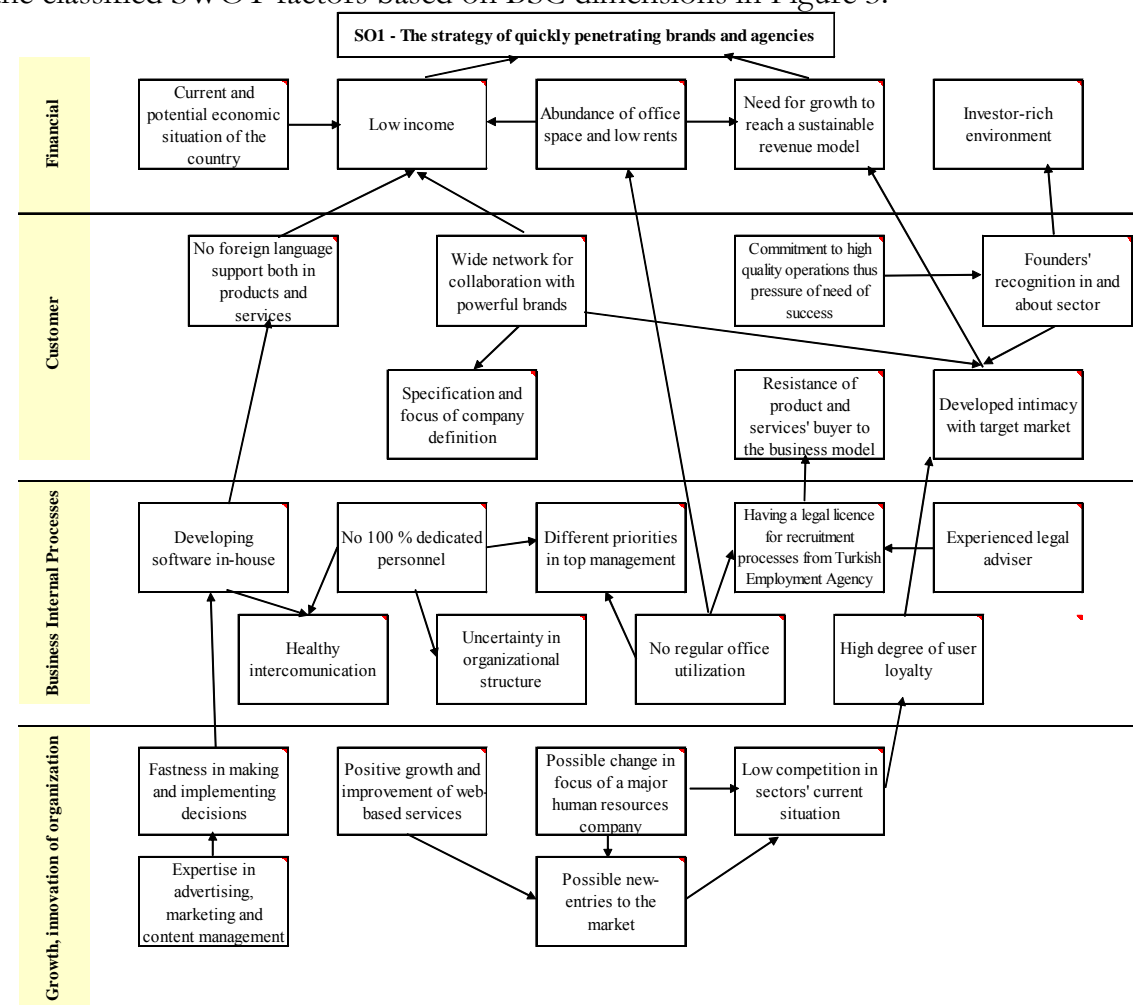

Figure 3. Strategic Map of the Start-up Company 
The sub-strategies which are defined on a workshop with decision makers to support the selected strategy are given in Table 8.

Table 8: The sub-strategies which support the best strategy

\begin{tabular}{|c|c|}
\hline Perspectives & Sub-strategies \\
\hline Finance & $\begin{array}{ll}\text { - } & \text { Increase income } \\
\text { - } & \text { Rent an office to sustain growth strategies }\end{array}$ \\
\hline Customer & $\begin{array}{l}\text { - } \text { Develop interfaces in foreign language } \\
\text { - Cooperate with blue chip brands } \\
\text { - Improve the relationships with the clients } \\
\text { - Campaign an advertisement which focus on the } \\
\text { company specialization }\end{array}$ \\
\hline Business Internal Processes & $\begin{array}{ll}\text { - } & \text { Recruit an operational personnel } \\
\text { - } & \text { Develop promotions to increase loyalty } \\
\text { - } & \text { Improve the software team } \\
\text { - } & \text { Speed up the software developing process } \\
\end{array}$ \\
\hline $\begin{array}{l}\text { Growth, innovation of } \\
\text { organization }\end{array}$ & $\begin{array}{l}\text { - Educate the managers to have different skills } \\
\text { - Focus on the web-based operations to differentiate } \\
\text { from the rivals }\end{array}$ \\
\hline
\end{tabular}

There are 12 sub-strategies defined to accomplish the main strategy. Decision makers decided to focus on renting an office strategy from the financial dimension. From customer dimension developing interfaces in foreign language, cooperating with blue chip brands and starting advertisement campaign strategies are selected. Recruiting an operational personnel and speeding up the software processes are selected from the business internal process dimension. Finally, focus on the web-based operations is selected from the last dimension.

\section{Conclusion}

In this paper a strategic management methodology is proposed for start-up companies. Strategic management is critical for start-up companies to avoid extinction and increase the probability of their survivability. The proposed method utilizes extended SWOT analysis to determine the strategies for which could be useful to improve the company. The method uses BSC approach to prioritize the determined strategies to find out the most important strategies which will affect most the success of the company.

The proposed method is applied to a start-up human resources consulting company. Human resources consulting companies have become more popular with the change in the business models. Companies which prefer to recruit the most adequate personnel in short time periods, utilize the rich portfolio and the experience of human resources consulting firms. This results in increasing number of start-up companies in this sector. To validate the proposed model it is applied for a start-up human resources consulting firm which displays that the proposed method is a useful tool to define the next strategy of a start-up company.

For the future researches it is recommended to apply the method to other start-up companies from different sectors. It is also recommended to compare the proposed method with the other common strategic management methods.

\section{References}

Boyett, I. and Currie, G. (2004). Middle Managers Moulding International Strategy: an Irish Start-up in Jamaican Telecoms 51. Long Range Planning,37(1).

David, F. R. (2009), Strategic management: concepts and cases, $1^{\text {th }}$ Edition, Prentice Hall. 
Davila, A., Foster, G., \& Jia, N. (2014). The Valuation of Management Control Systems in Start-Up Companies: International Field-Based Evidence. European Accounting Review, (ahead-of-print), 1-33.

Dyson, R. G. (2004). Strategic development and SWOT analysis at the University of Warwick. European journal of operational research, 152(3), 631-640.

Houben, G., Lenie, K., \& Vanhoof, K. (1999). A knowledge-based SWOT-analysis system as an instrument for strategic planning in small and medium sized enterprises. Decision support systems, 26(2), 125-135.

Hsu, D. H. (2006). Venture capitalists and cooperative start-up commercialization strategy. Management Science, 52(2), 204-219.

Jackson, S. E., Joshi, A., \& Erhardt, N. L. (2003). Recent research on team and organizational diversity: SWOT analysis and implications. Journal of management, 29(6), 801-830.

Kaplan, R. S. and D. P. Norton. (1992). The balanced scorecard - Measures that drive performance. Harvard Business Review, 70 (1), pp. 71-79.

Kaplan, R. S. and Norton, D. P. (2004),"The strategy map: guide to aligning intangible assets", Strategy \& Leadership, Vol. 32 Iss 5 pp. $10-17$.

Kazana, V., Kazaklis, A., Stamatiou, C., Koutsona, P., Boutsimea, A., \& Fotakis, D. (2015). SWOT analysis for sustainable forest policy and management: a Greek case study. International Journal of Information and Decision Sciences, 7(1), 32-50.

Nouri, J., Karbassi, A. R., \& Mirkia, S. (2008). Environmental management of coastal regions in the Caspian Sea. International Journal of Environmental Science \& Technology, 5(1), 43-52.

Patnaik, R. and Poyyamoli, G. (2014). Developing an eco-industrial park in Puducherry region, India-a SWOT analysis. Journal of Environmental Planning and Management, 1-21.

Tsalis, T. A., Nikolaou, I. E., Grigoroudis, E., \& Tsagarakis, K. P. (2013). A framework development to evaluate the needs of SMEs in order to adopt a sustainability-balanced scorecard. Journal of Integrative Environmental Sciences, 10(3-4), 179-197.

Wang, X., Ma, J., Zeng, Z., \& Zhao, J. (2008). Strategic choice of cities in the process of regional development. In Wireless Communications, Networking and Mobile Computing, 2008. WiCOM'08. 4th International Conference on (pp. 1-4).

Yüksel, İ., and Dagdeviren, M. (2007). Using the analytic network process (ANP) in a SWOT analysis-A case study for a textile firm. Information Sciences, 177(16), 3364-3382.

Zohrabi, A. and Manteghi, N. (2011). A proposed model for strategic planning in educational organizations. Procedia-Social and Behavioral Sciences, 28, 205-210. 
